\title{
The effect of ascorbic acid and soybean protein hydrolysate to iron binding capacity
}

\author{
Sri Peni Wijayanti", Erma Maryana, Ida Susanti, Noer Laily
}

Agency for The Assessment and Application of Technology, Center for Technology of Agroindustry - Gd. LAPTIAB (610) BPPT, PUSPIPTEK Serpong, Tangerang Selatan, Banten, Indonesia, 15314

\begin{abstract}
The study aimed to investigate the effect of ascorbic acid and soybean protein hydrolysate to iron-binding capacity. BPPT (Agency for the Assessment and Application of Technology) developed soybean hydrolysate, which was obtained by thermal and enzymatic hydrolysis. Ascorbic acid was added in sample preparation with composition 0, 50, 75 and 100\%. Soybean protein hydrolysate (SPH) was prepared by gel filtration chromatography using Sephadex G-25 to separate peptide based on molecular weight. Characterization of SPH and SPH fractions was also conducted, such as protein concentration, molecular weight, iron-binding capacity, and amino acid concentration. Iron binding capacity was determined by the colorimetric method using an ortho-phenanthroline reagent. The result showed that soybean protein hydrolysate increases iron-binding capacity 25-37 times than ascorbic acid. Arginine, aspartic acid, glutamic acid, threonine, lysine, and serine were found as amino acids responsible for iron-binding capacity in the SPH.
\end{abstract}

\section{Introduction}

Iron or Fe is a micromineral that is most abundant in the body and has an essential function in health. This mineral is also commonly found in food, but not a few people in the world, including Indonesia, still experience iron deficiency. This mineral deficiency can cause iron deficiency (anemia) with symptoms ranging from rapid fatigue, weakness, lethargy, dizziness, headaches, decreased performance, and others. Iron deficiency causes decreasing hemoglobin in the body, limiting the oxygen circulation and the energy produced by the body is not optimal.

Three main factors that affect iron absorption by the body such as the availability of iron in the body, iron bioavailability, and the presence of inhibiting factors for iron absorption. Iron contained in food can come from animals and plants. Iron from plants has an absorption capacity of 1-6\%, lower than iron from animals that have an absorption capacity of $7-22 \%$. The form of iron found in food also affects the absorption of iron by the body. There are two forms of iron in food, namely heme and non-heme. Heme iron comes from animals, its absorption does not depend on the type of other food content, and easier to absorb than non-heme iron. Although the heme-iron content in food is only between $5-10 \%$, its absorption reaches $25 \%$ (compare with non-heme iron whose absorption is only 5\%). Animal foods such as meat, fish, and chicken are the primary sources of heme iron. Hence, to increase its uptake, there have been many studies on iron fortification and supplements.

Iron can be supplied in salts, elemental iron, metal chelates, and iron-binding proteins or peptides (Hurrel, 2002; Gaucheron, 2000). Recent studies indicate that iron chelated peptides increase the stability, absorption, and bio-availability of iron (Miquel et al., 2007). Iron is a substance that is difficult to absorb by the body. In humans, the oral administration of ascorbic acid enhances the absorption of non-heme iron from the diet (Sayers et al., 1973) and leads to increases in serum iron in subjects with iron overload and the ascorbic acid deficiency (Wapnick et al., 1970). Moreover, iron overload states are associated with reduced ascorbic acid concentrations, possibly because of increased catabolism of ascorbic acid (Wapnick et al., 1970; Lynch et al., 1967). This study aimed to characterize the soybean protein hydrolysate (SPH) which is produced by thermal and enzymatic hydrolysis and to compare the iron-binding capacity with an ascorbic acid.

\section{Materials and methods}

\subsection{Chemicals and reagents}

The materials used in this study were SPH (developed by BPPT through steam blasting and enzymatic hydrolysis), Sephadex G-25 was obtained from GE Healthcare (Piscataway, NJ, USA). Other chemical reagents and solvents used in this study were of analytical grade and commercially available.

\subsection{Fractionation of soy protein hydrolysate (SPH)}

Fractionation of SPH was performed by gel filtration chromatography using Sephadex G-25 column $(1,5 \mathrm{~cm}$ x $170 \mathrm{~cm})$ attached to the Aktaprime instrument. Five $\mathrm{ml}$ sample was injected into the Aktaprime with $0,1 \%$ acetic acid as an eluent and flow rate of $0.3 \mathrm{ml} / \mathrm{min}$ at $1 \mathrm{mPa}$ pressure. The fractions were collected every $1 \mathrm{ml}$ and measured protein content with a UV detector at $280 \mathrm{~nm}$. From the chromatogram, it was obtained several peaks of protein or fractions. Furthermore, all the obtained fractions were analyzed for protein content, iron-binding capacity, protein profile using SDS-Page, and amino acid content using HPLC. 


\subsection{Characterization of SPH and the fraction of SPH}

\subsubsection{Determination of protein concentration}

The protein concentration was measured by Bradford Method (1976). The standard protein curve was made by measuring protein levels in a series of BSA (Bovin Serum Albumin) solution, concentrating at $0,50,100,200,300,400$, and $500 \mathrm{ppm}$. Ten $\mu \mathrm{l}$ of samples were added with $250 \mu \mathrm{l}$ Bradford reagents in 96 microplates well, then the samples were incubated for $10 \mathrm{~min}$. Measuring the samples at a wavelength of $450 \mathrm{~nm}$ and $595 \mathrm{~nm}$ was done using ELISA Reader. The data from measurement was analyzed by comparing it with the equation from the BSA standard calibration curve.

\subsubsection{Determination of molecular weight}

Molecular weight was measured by SDS-Page. This method used two gel parts, namely top gel (stacking gel) and bottom gel (separating gel), consisting of 4\% stacking gel concentration and separating gel $15 \%$. The concentration of the injected solution was different between a sample and low molecular weight (LMW) standard, which was $15 \mu \mathrm{L}$ and $4 \mu \mathrm{L}$, respectively. The composition of separating gel and stacking gel can be seen in Table 1 .

Table 1. Composition of separating gel and stacking gel for performing SDS-Page

\begin{tabular}{lll}
\hline Material & Separating gel, 15\% & Stacking gel, 4\% \\
\hline Water & $1.7 \mathrm{ml}$ & $2.7 \mathrm{ml}$ \\
Acrylamide $30 \%$ & $3.75 \mathrm{ml}$ & $0.67 \mathrm{ml}$ \\
Tris Buffer $1.5 \mathrm{M} \mathrm{pH} 8.8$ & $1.9 \mathrm{ml}$ & - \\
Tris Buffer 0.5 M pH 6.8 & - & $0.5 \mathrm{ml}$ \\
$10 \%$ SDS & $75 \mu \mathrm{l}$ & $40 \mu \mathrm{l}$ \\
$10 \%$ APS & $75 \mu \mathrm{l}$ & $40 \mu \mathrm{l}$ \\
TEMED & $3 \mu \mathrm{l}$ & $4 \mu \mathrm{l}$ \\
\hline
\end{tabular}

\subsubsection{Determination of iron-binding capacity}

SPH and the fraction of SPH were dissolved in a $20 \mathrm{mM}$ phosphate buffer ( $\mathrm{pH} 7.0$ ). After the addition of $5 \mathrm{mM} \mathrm{FeCl} \mathrm{F}_{2} \cdot 4 \mathrm{H}_{2} \mathrm{O}$, the solution was stirred at room temperature for $1 \mathrm{~h}$, and the reaction mixture was centrifuged at $3500 \mathrm{~g}$ for $20 \mathrm{~min}$ to remove precipitates. Meanwhile, the iron concentration in the supernatants was determined using a colorimetric method with orthophenanthroline reagent (Lee et al., 2009). The absorbance at 510 $\mathrm{nm}$ was determined after adding $1 \%$ hydroquinone and $0.25 \%$ ortho-phenanthroline reagent to the supernatant.

\subsubsection{Determination of amino acid content}

The amino acid analysis was carried out by utilizing the precolumn reaction of amino groups with certain reagents, forming a fluorinated compound. One of the most popular pre-column reagents is ortho-ftalaldehyde (OPA). OPA reagent will react with primary amino acids in an atmosphere containing mercaptoethanol bases to form fluorescent compounds, which could be detected by fluorescence detectors. The determination of amino acid content was carried out in the laboratory of PT. Saraswanti Indo Genetech.

\subsection{Iron-binding capacity of SPH and ascorbic acid in the} mixed solution

\subsubsection{Sample preparation}

The ascorbic acid solution was used at a concentration of 1270 ppm (3 times the concentration of $\mathrm{FeCl}_{2} 5 \mathrm{mM}$ ). In a $100 \mathrm{ml}$ volumetric flask, $1 \mathrm{gr}$ SPH was diluted with $50 \mathrm{ml}$ distilled water. Then, the mixture was shaken for $1 \mathrm{~h}$ and was centrifuged at 9000 $\mathrm{g}$ for $20 \mathrm{~min}$. The supernatant was separated to make the mixed solution that consisted of SPH and ascorbic acid. The composition of the mixed solution was as follows (SPH:ascorbic acid, 100:0; $75: 25 ; 50: 50 ; 25: 75$ and $0: 100 \%)$. Then, the samples were incubated for 1 hour at $25^{\circ} \mathrm{C}$ using an incubator shaker. After 1 hour, the samples were centrifuged at $3500 \mathrm{~g}$ for $20 \mathrm{~min}$. The supernatant was separated for iron-binding capacity.

\subsubsection{Determination of iron-binding capacity}

$\mathrm{SPH}$, and ascorbic acid, mixed solution (SPH and ascorbic acid) were dissolved in a $20 \mathrm{mM}$ phosphate buffer ( $\mathrm{pH}$ 7.0). After the addition of $5 \mathrm{mM} \mathrm{FeCl} 2.4 \mathrm{H}_{2} \mathrm{O}$, the solution was stirred at room temperature for $1 \mathrm{H}$, and the reaction mixture was centrifuged at $3500 \mathrm{~g}$ for $20 \mathrm{~min}$ to remove precipitates. Meanwhile, the iron concentration in the supernatant was determined using a colorimetric method with ortho-phenanthroline reagent (Lee et al., 2009). The absorbance at $510 \mathrm{~nm}$ was determined after adding 1\% hydroquinone and $0.25 \%$ ortho-phenanthroline reagent to the supernatant.

\section{Results and discussion}

\subsection{Fractionation of SPH}

SPH fractionation was carried out by gel filtration chromatography. Separation by gel filtration chromatography method was based on the size of the protein molecule and the difference in the size of the limiting material in the matrix. The matrices that are commonly used are cellulose and dextran. Small protein molecules will be trapped in the matrix, while molecules larger than the matrix size will be free and leave the chromatography column (Scopes, 1987). Sephadex G-25 was used in this study because Sephadex G-25 has a fractionation range for globular proteins of molecular weights (Mr) 1000 to 5000, with an exclusion limit of approximately Mr 5000. Proteins and peptides larger than Mr 5000 are therefore easily separated from molecules with molecular weights of less than 1000 . There were three peaks correlated with protein fractions from SPH (Fig. 1). The SPH was fractionated by gel filtration chromatography on a Sephadex G-25 column $(1.5 \mathrm{~cm} \times 170 \mathrm{~cm})$, and three peaks were pooled separately and named F1, F2, and F3.

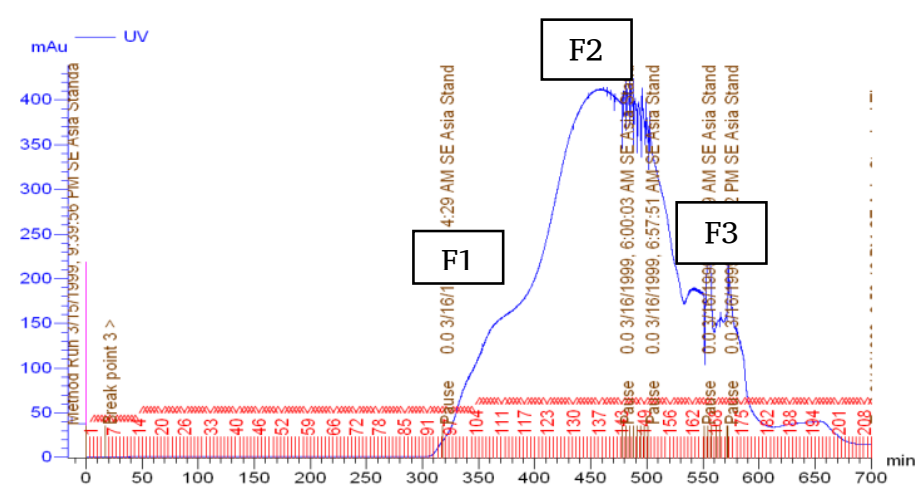

Fig. 1. Chromatogram of fractionated SPH

\subsection{Characterisation of SPH and its fractions}

\subsubsection{Protein concentration}

The protein concentration was measured by the Bradford method. The principle of this method is based on the formation of a blue complex. The formation of a blue complex is due to a bond between coomassie brilliant blue (CBB) dye and protein through ionic interaction between sulfonic acid groups with positive protein charges, namely the amine group by Van der Waals (Bio-Imaging System, 2006). The color change is due to the interaction between Bradford's reagents and the presence of certain amino acids contained in the protein. Free amino acids, peptides, and low molecular weight proteins do not produce a blue color with this reagent. The protein or peptide produced the blue color with molecular weight at least 3,000 daltons. The number of ligands that 
bind to the protein molecule is proportional to the positive charge of the protein. The absorbance amount is proportional to the protein content in the solution (Pierce, 2005). In this measurement, it was used two wavelengths, namely 450 and $595 \mathrm{~nm}$. The use of 2 wavelengths aimed to improve the accuracy and sensitivity of protein concentration measurements (Ernst and Zor, 2010). In this study, the protein concentration of SPH was higher than the SPH fractions. The protein concentrations of SPH fractions were 0.206 , 0.296 and $0.102 \mathrm{mg} / \mathrm{ml}$ for F1, F2 and F3, respectively (Table 2).

Table 2. Protein concentration of SPH, F1, F2, and F3

\begin{tabular}{ll}
\hline Sample & Protein concentration $(\mathrm{mg} / \mathrm{ml})$ \\
\hline SPH & $5.100 \pm 0.011$ \\
F1 & $0.206 \pm 0.005$ \\
F2 & $0.296 \pm 0.005$ \\
F3 & $0.102 \pm 0.003$ \\
\hline
\end{tabular}

\subsubsection{Molecular weight of SPH and its fractions}

Many proteins in the fractions and SPH were evenly distributed at molecular weight $10-20 \mathrm{kD}$ (Fig. 2). However, the thickening of the protein band was shown at a molecular weight below $10 \mathrm{kDa}$.
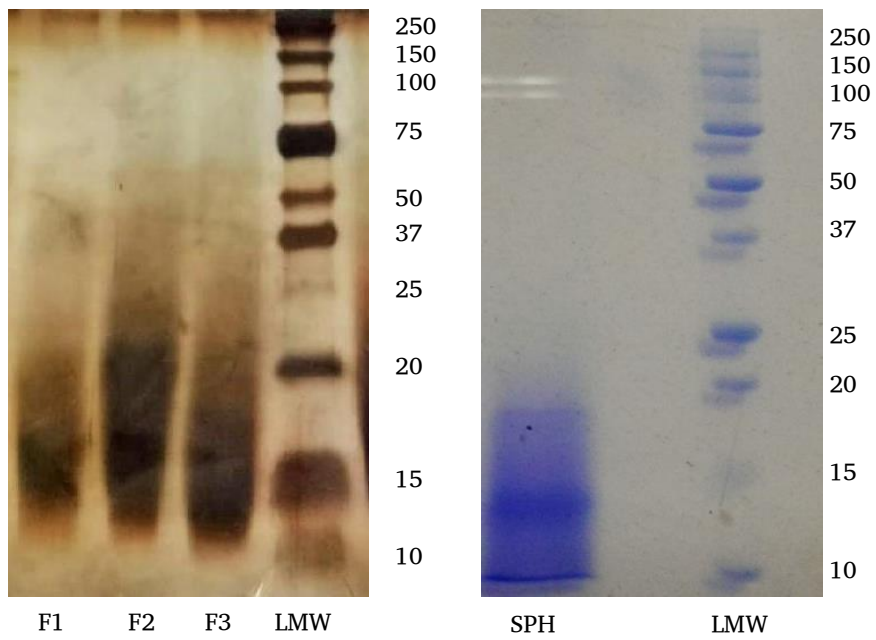

Fig. 2. SDS-page of protein from SPH, F1, F2, F3, and LMW

\subsubsection{Iron-binding capacity of SPH and its fractions}

Jung et al. (2006) stated that the ability of proteins or peptides to bind minerals is determined by the reaction mixture of soluble mineral concentration. Soy protein was hydrolyzed by bromelain enzyme to produce peptide or amino acids responsible for the iron chelation process. Through metal chelation, peptides or amino acids increase the solubility and bioavailability of metals. In Table 3 showed the iron concentration in SPH and SPH fractions. The iron concentration increased after the SPH was fractionated. However, the protein concentration of the SPH fractions was lower than the SPH (Table 2). Based on the iron-binding assay and protein concentration of each fraction, F2 had slightly higher iron-binding capacity than F1. According to the SPH fractions showed that the iron concentration increased along with an increase in protein concentration. The iron concentration for F2 was $46.746 \mathrm{ppm}$ at $0.296 \mathrm{mg} / \mathrm{ml}$ of protein concentration.

Table 3. Iron concentration of SPH, F1, F2, and F3

\begin{tabular}{ll}
\hline Sample & Iron concentration $(\mathrm{ppm})$ \\
\hline SPH & $7.025 \pm 0.042$ \\
F1 & $45.476 \pm 0.000$ \\
F2 & $46.746 \pm 0.044$ \\
F3 & $34.841 \pm 0.052$ \\
\hline
\end{tabular}

\subsubsection{Amino acid composition}

Li et al. (2017) stated that the iron-binding process involves protein hydrolysis products, namely amino acids di-, tri-, tetrapeptide, oligopeptides, and proteins. Amino acids responsible for binding iron include glutamic acid, aspartic acid, histidine, serine, cysteine, threonine, and arginine. Arginine has a free electron pair from nitrogen atom that can bind with positive ions of iron. Sóvágó and Ősz (2006) reported that glutamic acid and aspartic acid have negatively charged from carboxyl groups that can bind with positive ions of iron. Cates et al. (2002) and Kantarcia et al. (2005) reported that serine and threonine have negatively charged from the hydroxyl group that can bind with positive ions of iron. Lee et al. (2009) reported that lysine also has a high affinity for metal. In this study, SPH was fractionated using Sephadex G-25 into three fractions with different amino acid compositions for each fraction (Table 4). Based on the iron-binding capacity in Table 3, F2 showed that the iron concentration was slightly higher than F1 but higher than F3. The higher iron-binding ability in F2 was related to the amino acid content. F2 contained arginine, aspartic acid, threonine, lysine, and serine higher than F1 and F3. However, the glutamic acid content in F2 was slightly lower than F1.

Table 4. Amino acid content of F1, F2, and F3

\begin{tabular}{lllll}
\hline \multirow{2}{*}{ No. } & Amino acid & \multicolumn{3}{c}{ Amino acid content $(\mathrm{mg} / \mathrm{kg})$} \\
\cline { 3 - 5 } & & F1 & F2 & F3 \\
\hline 1 & Glycine & 141.55 & 70.11 & $<40.20$ \\
2 & Alanine & 207.15 & 55.20 & 114.15 \\
3 & Arginine & 70.27 & 94.11 & 30.32 \\
4 & Aspartic acid & 126.58 & 198.60 & 46.24 \\
5 & Glutamic acid & 431.80 & 392.19 & 60.64 \\
6 & Phenylalanine & 51.53 & 163.07 & 31.70 \\
7 & Histidine & - & - & - \\
8 & Isoleucine & 47.60 & 70.70 & 13.43 \\
9 & Leucine & 69.49 & 120.26 & $<22.58$ \\
10 & Lysine & 62.53 & 86.53 & $<15.63$ \\
11 & Proline & 267.58 & 90.89 & 137.80 \\
12 & Serine & $<83.02$ & 91.50 & - \\
13 & Threonine & 66.05 & 76.11 & $<22.94$ \\
14 & Tyrosine & $<22.29$ & 92.49 & $<22.29$ \\
15 & Valine & 49.88 & 72.19 & 16.52 \\
\hline
\end{tabular}

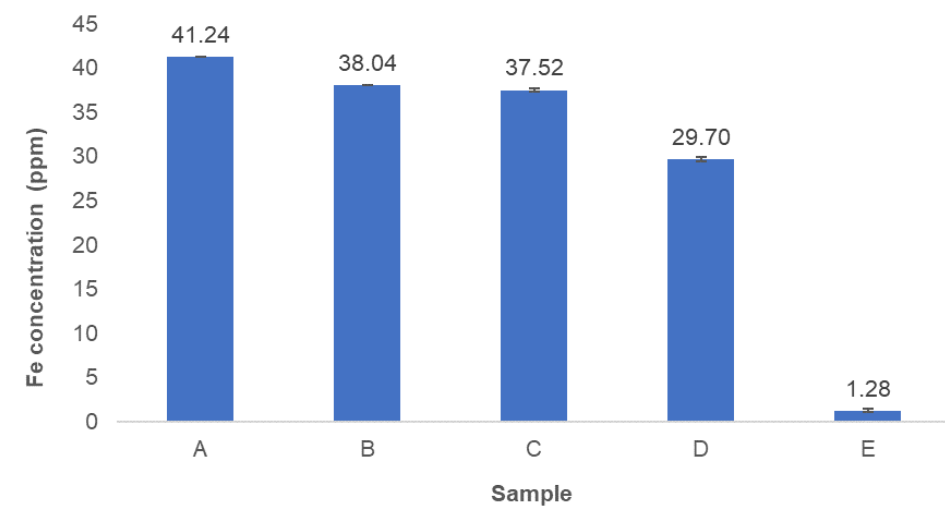

Fig. 3. Iron binding capacity for $\mathrm{A}=100 \% \mathrm{SPH}$; $=75 \%$ SPH : $25 \%$ ascorbic acid; $\mathrm{C}=50 \% \mathrm{SPH}: 50 \%$ ascorbic acid; $\mathrm{D}=25 \% \mathrm{SPH}: 75 \%$ ascorbic acid; $\mathrm{E}=100 \%$ ascorbic acid

\subsection{Iron-binding capacity of $\mathrm{SPH}$ and ascorbic acid}

Ascorbic acid or vitamin $\mathrm{C}$ is known as a substance that can increase iron solubility by reducing ferric ions to ferrous and prevents the formation of insoluble ferric hydroxide complexes (Benito and Miller, 1998). Meanwhile, SPH can increase iron solubility by forming a chelate between iron and amino acid residues (Li et al., 2017). In this study, SPH could increase the iron- 
binding capacity 25-37 times compared to ascorbic acid. The ironbinding capacity in a solution containing $100 \%$ SPH was higher than a solution containing $100 \%$ of ascorbic acid. The more SPH added to the mixed solution containing ascorbic acid, and the iron concentration increased in the mixed solution (Fig. 3). Eckert et al. (2016) showed that the peptide chelator from barley proteins might provide an alternative option to enhance iron absorption. They were more stable during storage and food processing than vitamin C.

\section{Conclusion}

This study demonstrates that SPH can be employed to produce iron-chelating peptides better than ascorbic acid. The iron-chelating ability of peptides has no relationship with their molecular weights but rather with their amino acid residues, especially arginine, aspartic acid, glutamic acid, threonine, lysine, and serine. Soybean protein is a suitable raw material for producing iron-binding peptides, which could serve as organic sources of mineral ions for food fortification. Further research is needed to determine the peptide sequences from SPH that are responsible for iron-binding. Overall, the iron-binding peptide from SPH has promising potential for the manufacture of functional food products as a supplement to iron.

\section{Acknowledgement}

Authors thank Center for Technology of Agroindustry - BPPT for providing fund and facilities for the research.

\section{Conflict of Interest}

The authors declare there is no conflict of interest in this study.

\section{References}

Benito P, Miller D. 1998. Iron absorption and bioavailability: an updated review. Nutr Res 18(3): 581-603. doi: 10.1016/S0271-5317(98)00044$\mathrm{X}$
Bio-Imaging System. 2006. Application Note \#2. Coomassie Brilliant Blue. Information Online.

Cates MS, Teodoro ML, Phillips GN. 2002. Molecular mechanisms of calcium and magnesium binding to parvalbumin. Biophys $J 82(3): 1133-46$. doi: 10.1016/S0006-3495(02)75472-6

Eckert E, Lu L, Unsworth LD, Chen L, Xie J, Xu R. 2016. Biophysical and in vitro absorption studies of iron-chelating peptide from barley proteins. J Funct Foods 25: 291-301. doi: 10.1016/j.jff.2016.06.011

Ernst O, Zor T. 2010. Linearization of the bradford protein assay. Jove- $J$ Vis Exp 38: e1918. doi: 10.3791/1918

Gaucheron F. 2000. Iron fortification in dairy industry. Trends Food Sci Technol 11(11): 403-9. doi: 10.1016/S0924-2244(01)00032-2

Hurrell R. 2002. How to ensure adequate iron absorption from iron-fortified food. Nutr Rev 60(7 pt 2): S7-15. doi: 10.1301/002966402320285137.

Jung WK, Lee BJ, Kim SK. 2006. Fish-bone peptide increases calcium solubility and bioavailability in ovariectomized rats. Br J Nutr 95(1): 124-8. doi: 10.1079/bjn20051615.

Kantarcia N, Tamerlerb C, Sarikayab M, Haliloglua T, Dorukera P. 2005. Molecular dynamics simulations on constraint metal-binding peptides. Polymer 46(12): 4307-13. doi: 10.1016/j.polymer.2005.03.016

Lee SH, Song KB. 2009. Purification of an iron-binding nonapeptide from hydrolysates of porcine blood plasma protein. Process Biochem 44(3): 378-81. doi: 10.1016/j.procbio.2008.12.001

Li Y, Jiang H, Huang G. 2017. Protein hydrolysates as promoters of nonhaem iron absorption. Nutrients 9(6): 1-18. doi: 10.3390/nu9060609

Miquel E, Farre' R. 2007. Effects and future trends of casein phosphopeptides on zinc bioavailability. Trends Food Sci Technol 18(3): 139-43. doi: 10.1016/j.tifs.2006.11.004

Pierce. 2005. Protein Assay Technical Handbook. PIERCE Biotechnology, Inc Sayers MH, Lynch SR, Jacobs P, Charlton RW, Bothwell TH, Walker RB, Mayet F. 1973. The effects of ascorbic acid supplementation on the absorption of iron. Br J Haematol 24(2): 209-18. doi: 10.1111/j.13652141.1973.tb05741.x

Scopes RK. 1984. Protein purificaton: principles and practices. New York: Springer

Sóvágó I, Ősz K. 2006. Metal ion selectivity of oligopeptides. Dalton T 32: 3841-54. doi: 10.1039/b607515k

Wapnick AA, Bothwell TH, Seftel H. 1970. The relationship between serum iron levels and ascorbic acid stores in siderotic Bantu. Br J Haematol 19(2): 271-6. doi: 10.1111/j.1365-2141.1970.tb01624.x 